\title{
Cost Minimisation in Sample Development and Approval Process by Proper Merchandising Action for kids and Ladies Garments
}

\author{
Anowar Hossain ${ }^{1 *}$ and Ashis Kumar Samanta ${ }^{2}$ \\ ${ }^{1}$ Department of Textile Engineering, City University, Dhaka, Bangladesh \\ ${ }^{2}$ Department of Jute and Fibre Technology, University of Calcutta, India \\ *Corresponding author: Anowar Hossain, Department of Textile Engineering, City University, Dhaka, Bangladesh

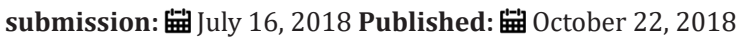

\begin{abstract}
Sample development and approval process of kids and ladies garments in export oriented knit garments factories for foreign buyers have been virtually observed to find out the critical lacking points of sample developers, merchandising department of factories and different causes of its delay approval of buying house merchandising department. The buyer asked for different types of sample during order confirmation to bulk production and requested to the factory merchandisers for sending the sample in a specific date to maintain the goals of order completion wherever merchandisers tried to fulfil the requirements. Sending date of sample from the concern of factory merchandisers and approval date of sample from the concern of buying house merchandisers were noted as per buyer's details and order details of different products like T-Shirt LS (Kids), Tops (Ladies), Tops \& Bottom LS (Ladies) and Shorts \& Skirt (Ladies). Sample development and approval process considering sample making time and sample approval time of a specific foreign buyer of Europe country was deeply studied in a knit garments factory and studied the sample related problem during sample making as well as investigated the time of sample approval. Significant outputs were found both in technological and marketing points of view which are 1) Fabric problem, color shade matching of fabric, azo \& formaldehyde presence in both fabric dyeing and printing in sample stage, shade matching of accessories \& sewing thread, seam puckering, sewing quality, Shrinking of garments, sample finishing \& unskilled technician in sample department were affected the time of sample making and sample approval. 2) Due to technical limitation of photo printing in sample where customers were making demand of actual view \& shade matching of photo print, but in real case it was impossible because of technical limitation by the factory concern which was taking more time of sample making and approval. 3) Color shade matching in printing was not possible like as the matching of fabric color matching which was not accepted by the buying house merchandiser but practically no spectrophotometer machine was using to match the color matching of print design which was taking more time for sample making and sample approval. 4) Sometimes buying house merchandiser was unable to understand the sample making and it was solved by the effective discussion between the experienced holder person of factory \& buying house merchandiser. Time in sample making and approval affected the confidence level of customer and order quantity of bulk production. Among all the order of Company-A, Order No: 123561 took minimum time for sample approval and Order No: 123928 took maximum time for sample approval. The m/c layout of the sample section in company-A was also investigated and found not in order, from where we first collected data when worked with merchandising department of Company-A. The same data was observed for company-B during the sample development and approval process in knit garments for this case study.
\end{abstract}

Keywords: Foreign buyer; Knit garments; Merchandising; Sampling; Sample approval

\section{Introduction}

There has been a significant and continuous interest in research on sample development and approval process from the cornerstone of garments factory and its merchandising. Merchandising department always facing a crucial situation to develop their sample within specific time period as per concrete demand of foreign customer in Bangladesh readymade garments manufacturing sector. The challenge in merchandising is directly related to achieve higher quantity of bulk order from international market as well as customer satisfaction. The performance of merchandising is also related to develop sample with technical and professional manner of sample making in knit garments industry.

The tremendous success of readymade garment exports from Bangladesh over the last two decades has surpassed the most optimistic expectations. Today the readymade garment sector is a multi-billion-dollar manufacturing and export industry in the country. The New York Times and the US Department of State reported in 2012 that low productivity due to low skill, poor management, insufficient infrastructure, inefficient machinery, and power cuts are the main challenge for the RMG sector. Sample development in any export-oriented garments industry plays a vital role for getting order of foreign buyer. The purpose of sampling is not only to get bulk order and it gives some additional benefits to the exporters. By doing sampling the exporter can estimate the yarn consumption for developing the fabric, a clear idea on costing and manufacturing difficulties. Besides by doing sampling the exporter can optimize the processing parameters for mass production, which helps to avoid all kinds of bottle necks. So it is essential that the samples should be innovative and with optimum quality. Design/Sketch->Basic Block->Working Pattern->Sample Making. 
This is the basic sample development process of overall knit wears worldwide. Many factories edit the development process to achieve their benefit and to get more efficient development process. So thus, the development process varies in each factory. So, varies the end result for that. The process of sample department varies from one context to another, and the development process covers a wide range of diverse.

products from new fibers, fiber blends, new yarns, fabric structures, finishes and surface effects and all types of made up products such as knitwear, hosiery, cut and sewn garments, household products, technical and medical products. There are different phases of sampling. The first phase covers the development of the initial concept or design idea through its approval by the customer and full review/risk analysis by the development and production teams. The second phase covers the process following acceptance of the first prototype sample and includes the functions of sourcing and ordering component, testing the product and carrying out trails once the finalized sample specifications has been drawn up, the third and final phase commences. The phase includes range of activities that are carried out before large scale or bulk production capacity outside the home producer/developers wherever this is applicable. We may have to spend too much on these samples. But these samples are inevitably important to develop business. Sometimes, even the buyer is not so confident of some enquiries, if our samples are good and attractive at reasonable prices, they will bring orders to us. Also, we will have to send samples to the newly contacted buyers to show our workmanship, product range, quality standards and price level. These samples should be sent so that they would attract the buyers. So, it is better for a company to have a separate sampling department so that they can create new styles in new fabrics to impress the buyers. A case study is represented here for Sample making and approval time process and its cost minimization by study being done in two Companies A and B and is reported.

A communication process of apparel merchandising was developed in apparel product development process [1]. By the investigation and interview on the spot, this article has analysed the bra design requirements and characteristics of female undergraduates from the southern region. It gained that their breasts were a bit small, mainly wearing 70A 70B. And they liked the general cotton bras with steel, dismountable shoulder straps and $3 / 4$ cups. It has also analysed the shortage of bra design at present, drawing the conclusion that the phenomenon of bra's unfitness and uncomfortableness commonly existed. Then based on the analysis, it has also put forward proposals about bra design to help underwear enterprises develop the southern region of the bra market of female undergraduates [2]. India has become the sought-after destination for global brands and retailers owing to escalating consumerism, unprecedented awareness and youth centric customer base. The apparel retail sector in India has really emerged as a successful venture owing to its more than $35 \%$ share in the overall retail sector in India. The study Recent fiends and Developments in Apparel Retailing in India is mainly dealing with apparel retailing covering some of the popular malls in India [3].
Fashion industry requires talented executives with a keen sense of the marketplace and finely honed management skills that enable them to make the critical decisions needed to keep a company's product line competitively marketable and profitable. The driving force in today's apparel business is merchandising. A merchandiser is defined as a person who ensures that the right product at the right price reaches in right quantity and at the right time to the destination. A merchandiser is the responsible person to make the product according to the buyer's parameters and satisfaction. Merchandisers have to look after every job right from buying the raw material, components and accessories, making the apparel, finishing the apparel, documentation and communication to and from all business partners to finally shipping and much more. The merchandisers play the role of a 'fulcrum' within apparel export organisations, coordinate and balance the business needs of the supplier on one end and buyer on the other. Their performance affects the business results of apparel export companies. The paper aims to identify the key parameters for assessing merchandisers' performance in apparel export companies. The recommendations based on key findings of the research show that merchandiser selection process, training and performance appraisal could significantly contribute towards improving the performance of merchandisers in the apparel industry [4].

Specific study examines factors that influence consumer behavior regarding the usage intentions and repurchasing behavior of counterfeits. Based on the Theory of Planned Behavior by Ajzen (1991), this study looks at the impact of attitude, subjective norm, perceived behavioural control, as well as the moral norm of consumers about intentions to use and repurchase counterfeits. An online survey was conducted on males and females over the age of 20 with previous experiences of purchasing counterfeits; subsequently, 209 responses were collected and analysed. The covariance structure model was used to analyze the data in order to measure the factors that influence the usage of counterfeits and repurchasing behavior. The results show that attitude, subjective norm, and perceived behavioural control have significantly positive effects on usage intentions, while moral norm has a significantly negative effect on usage intentions. Usage intentions also have a significantly positive effect on repurchasing behavior and confirmed that usage intentions functions as the mediator. The variables that influence usage intentions are attitude, perceived behavioural control, moral norm, and subjective norm, in descending order. Consumer attitudes towards counterfeits is a major factor that influences usage intentions. Therefore, ethical problems should be emphasized to encourage a negative attitude towards counterfeits. This study identifies an important aspect to show that usage intentions toward counterfeits, and not purchasing intentions, influences repurchasing behavior. Findings are significant in that they reveal the role of the moral norm variable added to the TPB model [5]. Through using AIOV analytical method to study on Young-Adult female consumer in Shanghai, the paper gains the general character of this consumption group. According to the analysis of this target market, the paper establishes the merchandising strategy for brand "Cacao". In order to meet the 
sensibility of apparel consumption, the paper puts forward a kind of calculated overture for creating the individual brand [6]. The consumption feature and demand of women from four cities in south Jiangsu were studied through questionnaire survey. Some conclusions were obtained. The consumption demands of shaping underwear included four factors: functional factor, quality factor, appearance factor and performance factor. Several strategies about the development and sale of shaping underwear were proposed based on the above conclusion, such as improving the comfort and the functionality, determining the design style and idea, enhancing products cost performance and improving the quality of service [7].

As a special consumer groups, female undergraduate's underwear consuming behavior has become a special style, which should receive adequate attention. Taking bras and underpants as the study objects, by the questionnaire survey, underwear consuming behavior and characteristic were analysed. Then on the basis of that, it has also put forward several proposals about underwear production and sales to help underwear enterprises make marketing plan and develop the southern region of the lingerie market of female undergraduates [8], (Figure 1-3). Men's product development based on the era of big data network pattern research, men's clothing development by network as the main research object, through the research and planning, design and development, pricing and listing three constitute the basic content of the men's clothing development expand, combined with the background of the era of big data network data statistics, inquiry based on men's clothing development in the era of big data network model. The model can make the network of men's clothing brand enterprise product development more scientific, effective and better adapted to the rapid response network clothing consumption market [9]. Began with the aspect of ergonomics, analysed some important problems in construction. Then from change some items of construction, such as the breadth of the crotch, the inclined angle of the inseam, the crotch depth and the creases pressed-in studied the relationship between the construction and comfort of the pants, Finally, explain the relationship by an illustration [10]. Various attributes of merchandisers' performance at organisation level and parameters of supply chain competitiveness that affect the apparel industry [11].

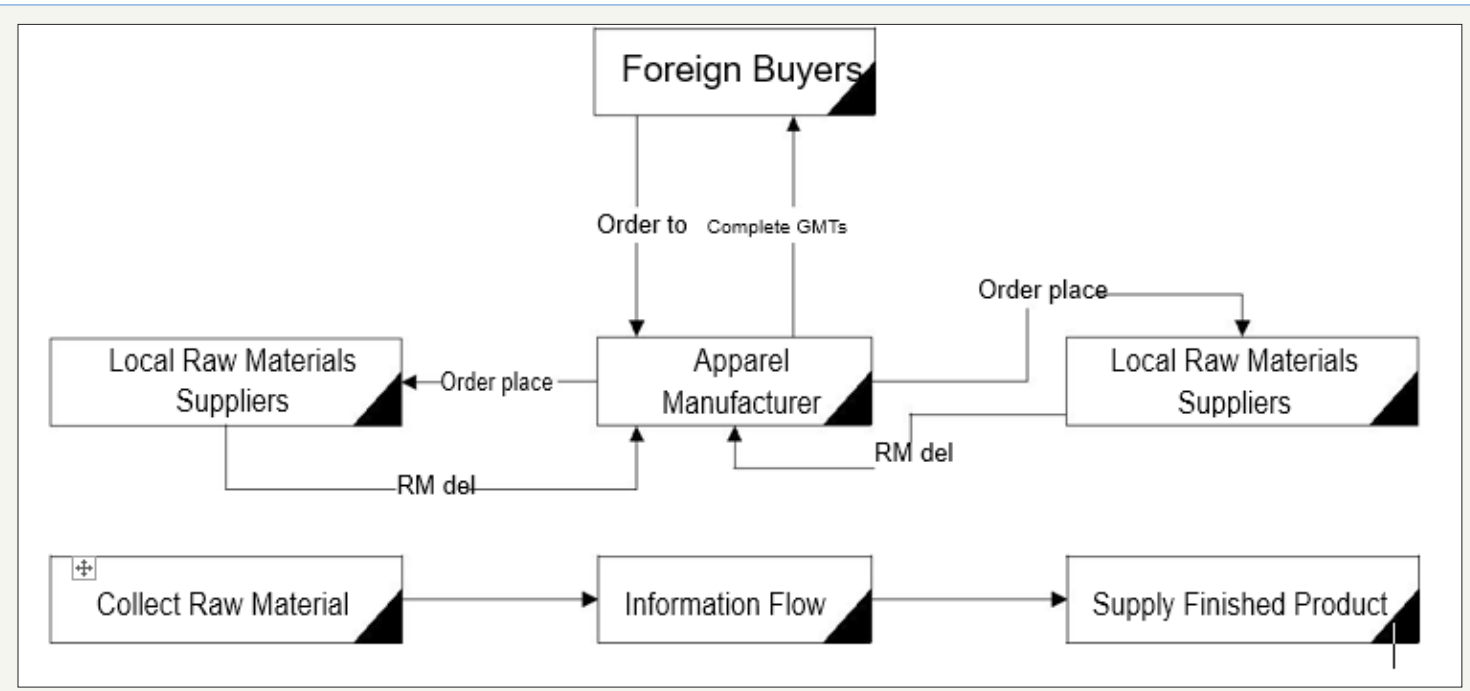

Figure 1: Business structure and raw materials suppliers [12].

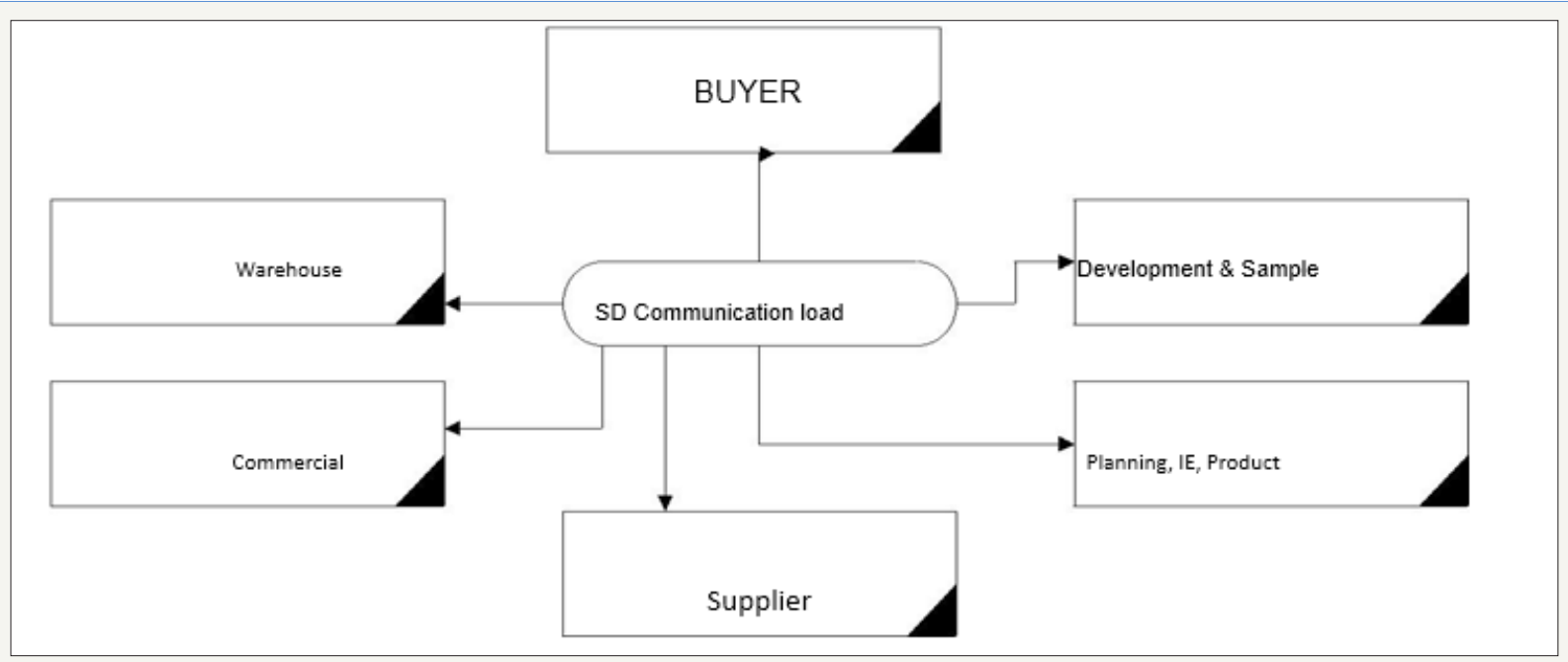

Figure 2: Merchandiser/sales \& distribution communication load, [12]. 


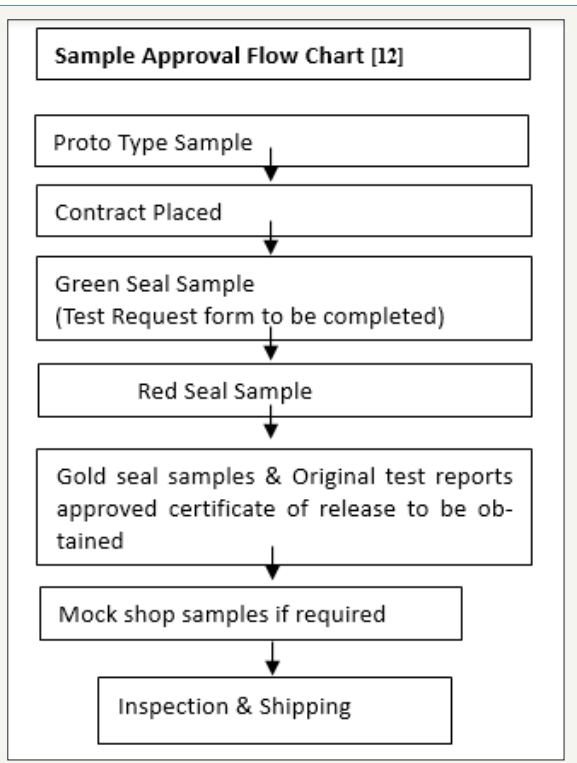

Figure 3:

Nuruzzaman [12] studied an attempt which established to find out the ways to face the competitive business environment by the efficient management process towards the lead time reduction as well as analysed the business process of the garment sector to find out its lead time minimization process [12]. Farhan [13] occupied with different parties i.e. the suppliers, manufacturers, buyers etc. are involved in different phases of supply chain of this industry, every stage (procurement, manufacturing, replenishment, customer order) is conflicting with its next stage with the goals and objectives. In this conceptual model, attempts have been taken to create the layout and design of the procurement of raw materials, work-in-process, inventory and finished goods from various sources to the ultimate consumer in this garment business [13].

Mahmuda [14] confirmed the conceptual model has been provided by this study helps apparel manufacturer to make the cost-effective working process of collecting raw materials as well as reduce the time. This operation model of raw materials creates scope to optimize the supply chain working procedure of this industry. The work load of merchandising will be reduced by implementing this model practically, which help to create efficient team and helpful to remove obstacles which are faced by merchandising team during apparel production. Thus, they can meet up the buyer's critical path schedule and export within the lead time. Finally, this model will help to enhance the production process flow [14]. Behrooz [15] conducted a survey and individual interview with senior management personnel, supply chain professionals, and merchandisers of the RMG industry. Based on the findings, a causal loop diagram is proposed to help understand the dynamic behavior among the said variables so that the top management may take effective decisions to enhance the supply chain performance in the long run [15].

\section{Experimental Details}

Technical data of the following products was collected from merchandising department of Company-A, West Bengal, India and from Company-B, Chittagong, Bangladesh. When we worked for this case study with the said two factories, the sample development process of Foreign buyer for sample development was available in the sample section \& merchandising department for several products like T-Shirt LS (Kids), T-Shirts SS (Kids), Tops (Ladies), Tops \& Bottom LS (Ladies), Pant Shorts \& Skirt (Ladies) in both Companies A and B. Studied the sample development process of T shirt (Hoody) \& merchandising department was asked to send photo, production \& License approval sample with the requirement of test like Azo, color fastness, color fastness to perspiration \& rubbing), fabric color, print color \& design \& fabric with $80 / 40$ cotton/polyester. As per the requirement sample was developed \& noted sample making and approval process was studied in both the companies A and B. Experimental Data Collection from merchandising department and sample making department: Data of Case Study can be compared from data given in annex Tables 1 $\& 2$.

Table 1: Date wise data on different types of sample approval time (Day) of Company-A and B for kids and ladies garments.

\begin{tabular}{|c|c|c|c|c|c|c|c|c|c|c|c|c|c|c|c|}
\hline \multirow[t]{2}{*}{$\begin{array}{l}\text { Exp. } \\
\text { no: }\end{array}$} & \multirow[t]{2}{*}{$\begin{array}{c}\text { Or- } \\
\text { der } \\
\text { no }\end{array}$} & \multicolumn{2}{|c|}{$\begin{array}{c}\text { Size Set Sam- } \\
\text { ple }\end{array}$} & \multicolumn{2}{|c|}{ Revised Sample } & \multicolumn{2}{|c|}{ Photo Sample } & \multicolumn{2}{|c|}{$\begin{array}{l}\text { Reverse } \\
\text { Sample }\end{array}$} & \multicolumn{2}{|c|}{$\begin{array}{l}\text { Pre-production } \\
\text { Sample }\end{array}$} & \multicolumn{2}{|c|}{$\begin{array}{l}\text { Production } \\
\text { Sample }\end{array}$} & \multicolumn{2}{|c|}{$\begin{array}{l}\text { Lisence Approv- } \\
\text { al Sample }\end{array}$} \\
\hline & & $\begin{array}{c}\text { Send- } \\
\text { ing } \\
\text { date }\end{array}$ & $\begin{array}{c}\text { Ap- } \\
\text { proval } \\
\text { date }\end{array}$ & $\begin{array}{l}\text { Send- } \\
\text { ing } \\
\text { date }\end{array}$ & $\begin{array}{l}\text { Approval } \\
\text { date }\end{array}$ & $\begin{array}{l}\text { Sending } \\
\text { date }\end{array}$ & $\begin{array}{c}\text { Ap- } \\
\text { proval } \\
\text { date }\end{array}$ & $\begin{array}{l}\text { Send- } \\
\text { ing } \\
\text { date }\end{array}$ & $\begin{array}{c}\text { Ap- } \\
\text { proval } \\
\text { date }\end{array}$ & $\begin{array}{l}\text { Sending } \\
\text { date }\end{array}$ & $\begin{array}{l}\text { Approv- } \\
\text { al date }\end{array}$ & $\begin{array}{l}\text { Sending } \\
\text { date }\end{array}$ & $\begin{array}{c}\text { Ap- } \\
\text { proval } \\
\text { date }\end{array}$ & $\begin{array}{c}\text { Send- } \\
\text { ing } \\
\text { date }\end{array}$ & $\begin{array}{l}\text { Approv- } \\
\text { al date }\end{array}$ \\
\hline \multicolumn{4}{|c|}{ Company-A (Kids) } & & & & & & & & & & & & \\
\hline
\end{tabular}




\begin{tabular}{|c|c|c|c|c|c|c|c|c|c|c|c|c|c|c|c|}
\hline 01 & $\begin{array}{l}12 \\
26 \\
75\end{array}$ & $\begin{array}{c}28 / \\
09 / \\
2016\end{array}$ & $\begin{array}{c}11 / \\
10 / \\
2016\end{array}$ & & & $\begin{array}{l}15 / \\
10 / \\
2016\end{array}$ & $\begin{array}{l}26 / \\
10 / \\
2016\end{array}$ & & & & & $\begin{array}{l}15 / \\
11 / \\
2016\end{array}$ & $\begin{array}{l}24 / \\
11 / \\
2016\end{array}$ & & \\
\hline 02 & $\begin{array}{l}12 \\
26 \\
74\end{array}$ & $\begin{array}{l}28 / \\
09 / \\
2016\end{array}$ & $\begin{array}{c}11 / \\
10 / \\
2016\end{array}$ & & & $\begin{array}{c}15 / \\
10 / \\
2016\end{array}$ & $\begin{array}{l}26 / \\
10 / \\
2016\end{array}$ & & & & & $\begin{array}{c}15 / \\
11 / \\
2016\end{array}$ & $\begin{array}{l}25 / \\
11 / \\
2016\end{array}$ & & \\
\hline 03 & $\begin{array}{l}11 \\
86 \\
08\end{array}$ & & & & & $\begin{array}{c}15 / \\
01 / \\
2016\end{array}$ & $\begin{array}{l}26 / \\
01 / \\
2016\end{array}$ & $\begin{array}{c}29 / \\
01 / \\
2016\end{array}$ & $\begin{array}{c}12 / \\
02 / \\
2016\end{array}$ & & & $\begin{array}{c}28 / \\
02 / \\
2016\end{array}$ & $\begin{array}{l}09 / \\
03 / \\
2016\end{array}$ & & \\
\hline 04 & $\begin{array}{l}12 \\
36 \\
18\end{array}$ & $\begin{array}{l}05 / \\
04 / \\
2016\end{array}$ & $\begin{array}{c}16 / \\
04 / \\
2016\end{array}$ & & & $\begin{array}{c}20 / \\
04 / \\
2016\end{array}$ & $\begin{array}{l}02 / \\
05 / \\
2016\end{array}$ & & & & & $\begin{array}{l}30 / \\
05 / \\
2016\end{array}$ & $\begin{array}{l}10 / \\
05 / \\
2016\end{array}$ & $\begin{array}{c}30 / \\
05 / \\
2016\end{array}$ & $\begin{array}{c}10 / \\
05 \\
/ 2016\end{array}$ \\
\hline 05 & $\begin{array}{l}11 \\
81 \\
05\end{array}$ & & & & & $\begin{array}{c}15 / \\
01 / \\
2016\end{array}$ & $\begin{array}{l}27 / \\
01 / \\
2016\end{array}$ & & & & & $\begin{array}{l}28 / \\
02 / \\
2016\end{array}$ & $\begin{array}{l}09 / \\
03 / \\
2016\end{array}$ & $\begin{array}{c}28 / \\
02 / \\
2016\end{array}$ & $\begin{array}{c}09 / \\
03 / \\
2016\end{array}$ \\
\hline \multicolumn{16}{|c|}{$\begin{array}{l}\text { Company-B (Ladies Gar- } \\
\text { ments) }\end{array}$} \\
\hline 06 & $\begin{array}{l}12 \\
35 \\
61\end{array}$ & $\begin{array}{l}05 / \\
04 / \\
2016\end{array}$ & $\begin{array}{c}13 / \\
04 / \\
2016\end{array}$ & $\begin{array}{l}15 / \\
04 / \\
2016\end{array}$ & $\begin{array}{l}24 / \\
04 / \\
2016\end{array}$ & $\begin{array}{c}26 / \\
04 / \\
2016\end{array}$ & $\begin{array}{l}06 / \\
05 / \\
2016\end{array}$ & & & & & $\begin{array}{c}30 / \\
05 / \\
2016\end{array}$ & $\begin{array}{l}09 / \\
06 / \\
2016\end{array}$ & $\begin{array}{c}30 / \\
05 / \\
2016\end{array}$ & $\begin{array}{c}09 / \\
06 / \\
2016\end{array}$ \\
\hline 07 & $\begin{array}{l}12 \\
59 \\
62 \\
\end{array}$ & $\begin{array}{l}08 / \\
06 / \\
2016\end{array}$ & $\begin{array}{c}17 / \\
06 / \\
2016\end{array}$ & $\begin{array}{l}20 / \\
06 / \\
2016\end{array}$ & $\begin{array}{l}29 / \\
06 / \\
2016\end{array}$ & $\begin{array}{c}03 / \\
07 / \\
2016\end{array}$ & $\begin{array}{l}13 / \\
07 / \\
2016\end{array}$ & & & & & $\begin{array}{c}04 / \\
09 / \\
2016\end{array}$ & $\begin{array}{l}15 / \\
09 / \\
2016\end{array}$ & & \\
\hline 08 & $\begin{array}{l}12 \\
39 \\
28\end{array}$ & $\begin{array}{l}13 / \\
04 / \\
2016\end{array}$ & $\begin{array}{l}22 / \\
04 / \\
2016\end{array}$ & & & $\begin{array}{l}25 / \\
04 / \\
2016\end{array}$ & $\begin{array}{l}08 / \\
05 / \\
2016\end{array}$ & & & $\begin{array}{c}30 / \\
05 / \\
2016\end{array}$ & $\begin{array}{l}11 / \\
06 / \\
2016\end{array}$ & $\begin{array}{l}15 / \\
06 / \\
2016\end{array}$ & $\begin{array}{l}27 / \\
06 / \\
2016\end{array}$ & & \\
\hline
\end{tabular}

Table 2: Date wise data on different to sample making time (hour) of company-A and B for kids and ladies garments.

\begin{tabular}{|c|c|c|c|c|c|c|c|c|c|c|c|c|}
\hline $\begin{array}{l}\text { Exp. } \\
\text { No }\end{array}$ & Order no & $\begin{array}{r}\text { Size S } \\
\text { Maki }\end{array}$ & $\begin{array}{r}\text { Rever } \\
\text { Maki }\end{array}$ & $\begin{array}{l}\text { Sample } \\
\text { Time }\end{array}$ & $\begin{array}{l}\text { Photo Sample } \\
\text { Making time }\end{array}$ & \multicolumn{2}{|c|}{$\begin{array}{c}\text { Reverse } \\
\text { Sample } \\
\text { Making } \\
\text { Time }\end{array}$} & \multicolumn{2}{|c|}{$\begin{array}{l}\text { Pre-production } \\
\text { Sample Making } \\
\text { time }\end{array}$} & $\begin{array}{c}\text { Production } \\
\text { Sample Mak- } \\
\text { ing Time }\end{array}$ & \multicolumn{2}{|c|}{$\begin{array}{l}\text { License Ap- } \\
\text { proval Sample } \\
\text { Making Time }\end{array}$} \\
\hline \multicolumn{13}{|c|}{ Company -A (Kids) } \\
\hline 01 & 122675 & $5 \mathrm{hrs}$ & $6 \mathrm{hrs}$ & & $4 \mathrm{hrs}$ & & 01 & 122675 & $5 \mathrm{hrs}$ & $6 \mathrm{hrs}$ & & \\
\hline 02 & 122674 & $3.5 \mathrm{hrs}$ & $4 \mathrm{hrs}$ & & $2 \mathrm{hrs}$ & & 02 & 122674 & $3.5 \mathrm{hrs}$ & $4 \mathrm{hrs}$ & & \\
\hline 03 & 118608 & & $3 \mathrm{hrs}$ & $4 \mathrm{hrs}$ & $2 \mathrm{hrs}$ & & 03 & 118608 & & $3 \mathrm{hrs}$ & $4 \mathrm{hrs}$ & \\
\hline 04 & 123618 & $2 \mathrm{hrs}$ & $4 \mathrm{hrs}$ & & $3 \mathrm{hrs}$ & $3 \mathrm{hrs}$ & 04 & 123618 & $2 \mathrm{hrs}$ & $4 \mathrm{hrs}$ & & \\
\hline 05 & 118105 & & $4 \mathrm{hrs}$ & & $2 \mathrm{hrs}$ & $2 \mathrm{hrs}$ & 05 & 118105 & & $4 \mathrm{hrs}$ & & \\
\hline \multicolumn{13}{|c|}{ Company -B } \\
\hline
\end{tabular}




\begin{tabular}{|c|c|c|c|c|c|c|c|c|c|c|c|c|c|c|c|}
\hline 06 & 123561 & $3 \mathrm{hrs}$ & $3.5 \mathrm{hrs}$ & $\begin{array}{c}4.5 \\
\mathrm{hrs}\end{array}$ & & & $3 \mathrm{hrs}$ & $3 \mathrm{hrs}$ & 06 & 123561 & $3 \mathrm{hrs}$ & $\begin{array}{c}3.5 \\
\mathrm{hrs}\end{array}$ & $\begin{array}{c}4.5 \\
\mathrm{hrs}\end{array}$ & \\
\hline 07 & 125962 & $4 \mathrm{hrs}$ & $5 \mathrm{hrs}$ & $5 \mathrm{hrs}$ & & & $4 \mathrm{hrs}$ & & 07 & 125962 & $4 \mathrm{hrs}$ & $5 \mathrm{hrs}$ & $5 \mathrm{hrs}$ & & \\
\hline 08 & 123928 & $2 \mathrm{hrs}$ & & $3 \mathrm{hrs}$ & & $3 \mathrm{hrs}$ & $2 \mathrm{hrs}$ & & 08 & 123928 & $2 \mathrm{hrs}$ & & $3 \mathrm{hrs}$ & & $3 \mathrm{hrs}$ \\
\hline
\end{tabular}

\section{Methods of Data Collection}

(a) Sample development was observed according to technical data of a specific buyer with the active support \& cooperation of merchandising department \& product developer. Researchers were involved directly \& indirectly for studying sample making and approval process of said knit composite factory. (b) Receiving technical data which was primarily sent from buyer's office. (c) Forwarding technical data from merchandising department to related department like the fabric production (dyeing \& finishing), printing department, sample department \& accessories department. (d) Follow-up sample development stage in sample department. (e) Keeping record of Sample sending time to buying house \& approval receiving time from buying house. (f) Note down buyer's comments. (g) Re-editing \& resending sample according the requirements of customer. (h) Sample sending date counting and waiting for sample approval. (i) Getting sample approval by the merchandising department of factory. (j) Sending Sample to bulk production concern

Result and Discussions (Time Study of Sample Development)

\section{Experiment No: 01(Figure 4)}

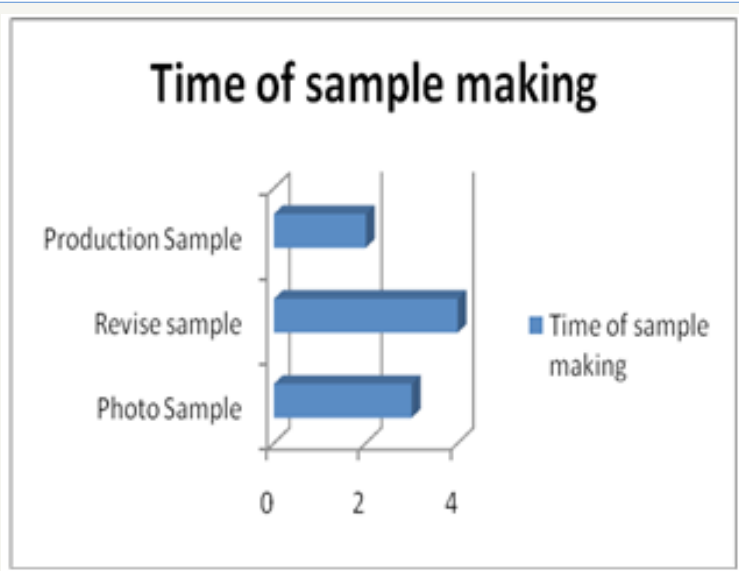

Figure 4: Time of sample making in hours for production sample, revised sample and photo sample.

In this experiment, researchers were found under discussion with sample developer and merchandiser. Revised sample was taking more time comparing to production sample and photo sample as well as photo sample was taking higher time than production sample due to followings:
a) Photo printed design development \& redesigning
b) Hoody attachment \& measurement matching
c) Late of outsourcing woven label and care label

d) Inside brushed fabric was used

e) $80 / 40$ cotton/polyester fabric dyeing \& shade making took more time

\section{Experiment No: 02(Figure 5)}

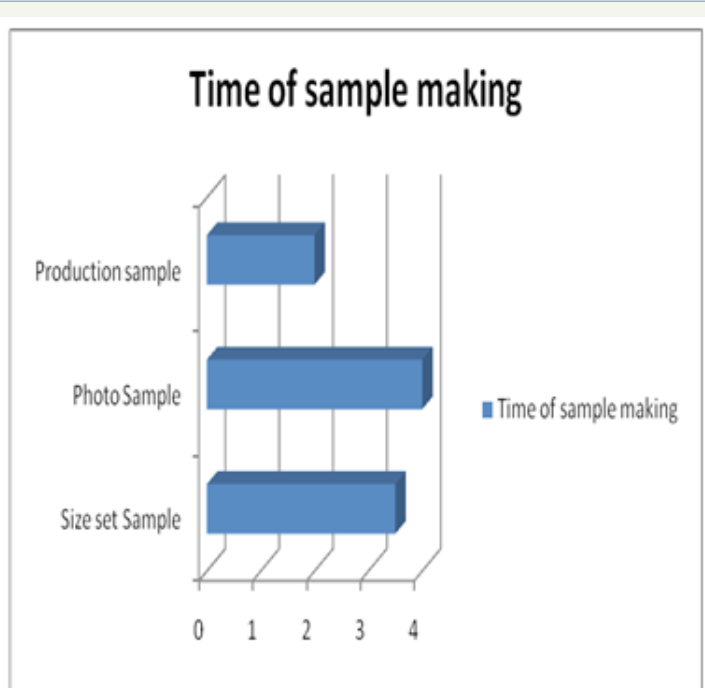

Figure 5: Time of sample making in hours for production sample, photo sample and size set sample.

Researchers were investigated that photo sample was taking higher time than size set and production sample due to followings:

a) Photo printed design development \& redesigning

b) Front side pocket joining

c) Testing color fastness, wash fastness and azo requirements of customer

\section{Experiment No: 03(Figure 6)}

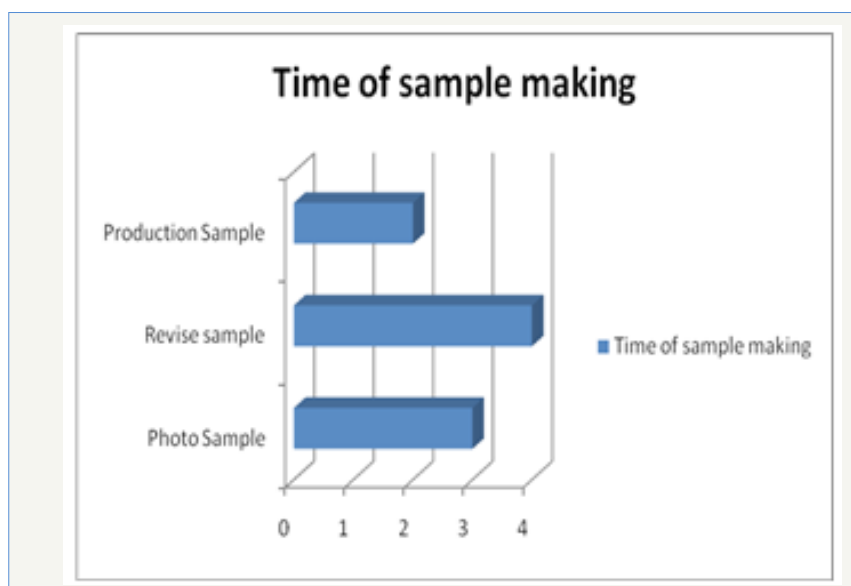

Figure 6: Time of sample making in hours for production sample, revised sample and photo sample. 
In this experiment, it was confirmed under discussion with sample developer and merchandiser that revised sample was taking more time comparing to production sample and photo sample as well as photo sample was taking higher time than production sample due to followings:
a) Photo printed design development \& redesigning
b) Multicolored fabric matching

\section{Experiment No: 04(Figure 7)}

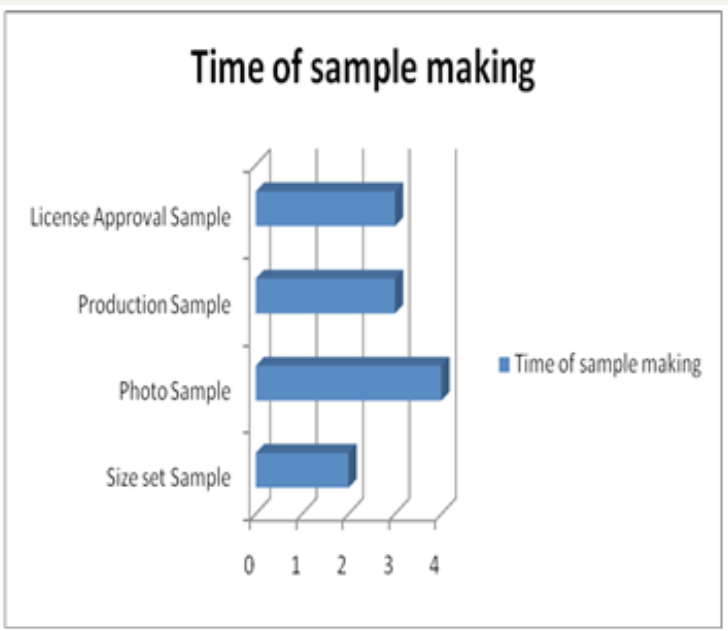

Figure 7: Time of sample making in hours for License approval sample, Production sample, Photo sample and Size set sample.

In this experiment, researchers were found under discussion with sample developer and merchandiser that photo sample was taking more time comparing to production sample, size set sample and license approval sample as well as photo sample was taking higher time than production sample due to followings:

a) Photo printed design development \& redesigning as per customer requirements.

\section{Experiment No: 05(Figure 8)}

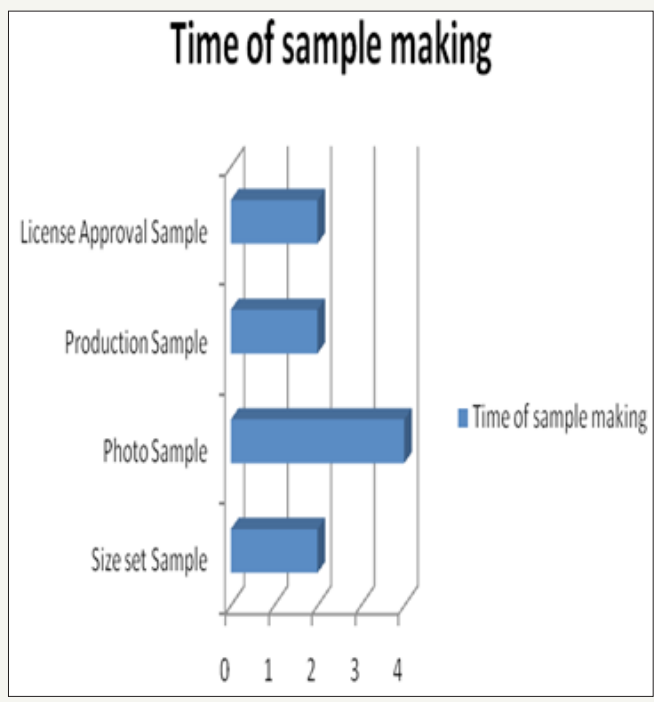

Figure 8: Time of sample making in hours for License Approval Sample, Production Sample, Photo sample and Size set sample.
In this experiment, investigators were found under effective discussion with sample developer and merchandiser that photo sample was taking more time comparing to production sample, Size set sample and license approval sample due to followings:

a) Photo printed design development \& redesigning

b) Late of outsourcing woven label and care label

c) Color shade matching of fabric \& photo print color

\section{Experiment No: 06(Figure 9)}

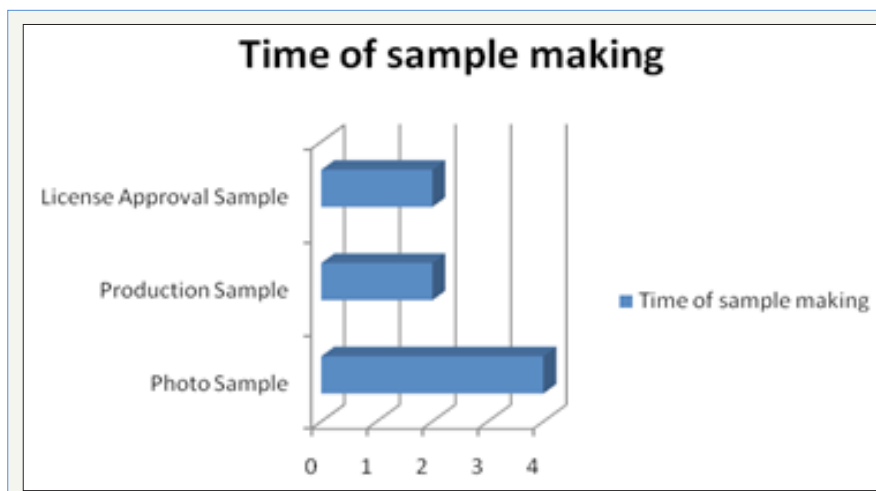

Figure 9: Time of sample making in hours for License approval sample, production sample, and photo sample.

Investigators were found under discussion with sample developer and merchandiser that photo sample was taking more time comparing to production sample and license approval due to followings:

a) Photo printed design development \& redesigning due to lacking designer's understanding.

\section{Experiment No: 07(Figure 10)}

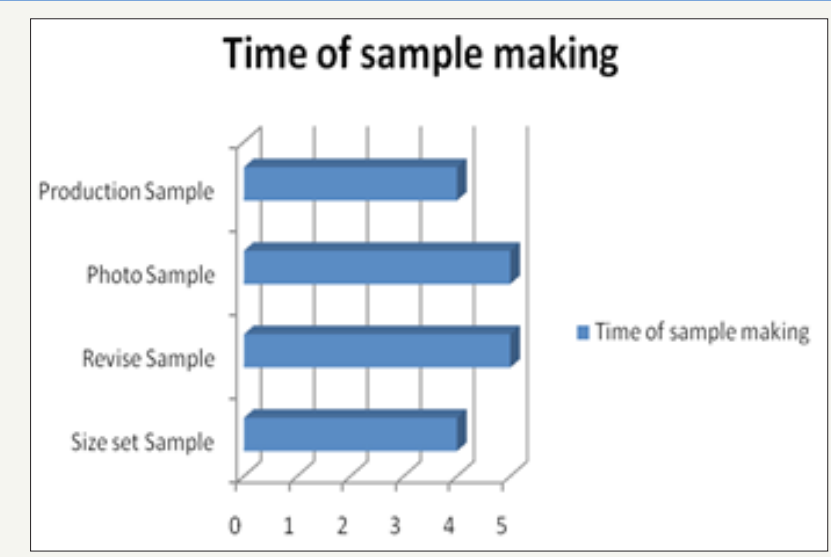

Figure 10: Time of sample making in hours for production sample, photo sample, Revised sample, Size-set sample.

Researchers were found under discussion with sample developer and merchandiser that both revised sample and photo sample were taking higher time than production sample and size set sample due to followings:

a) Photo printed design development \& redesigning

b) T-shirt \& legging

How to cite this article: Anowar H, Ashis K S. Cost Minimisation in Sample Development and Approval Process by Proper Merchandising Action for kids and Ladies 


\section{Experiment No: 08(Figure 11)}

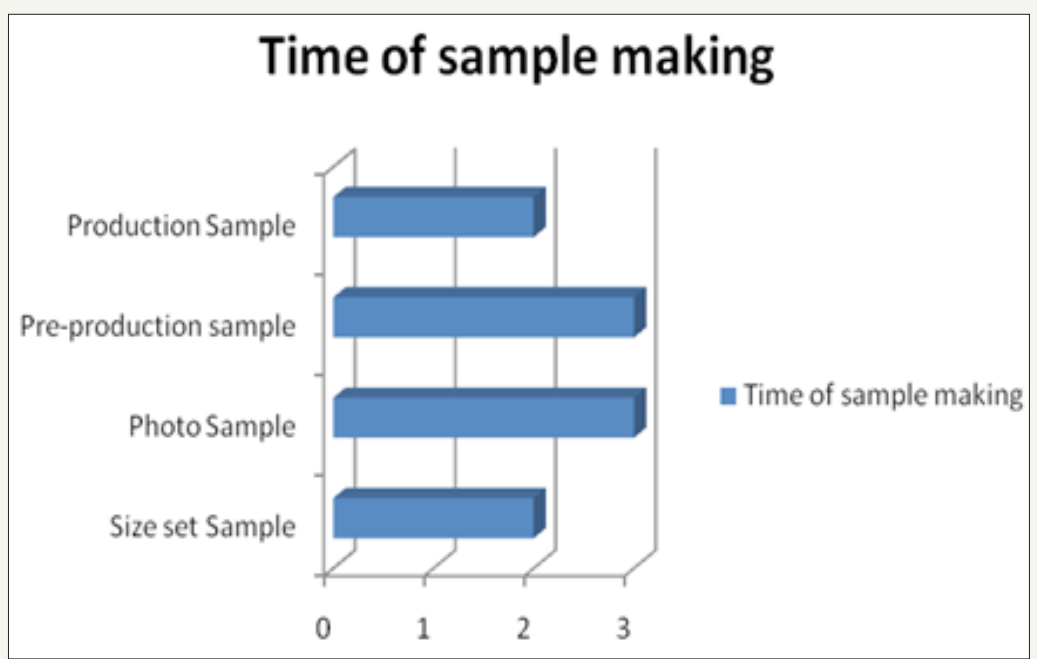

Figure 11: Time of sample making in hours for production sample, pre-production sample, photo sample and size set sample.

Reseachers were confirmed with discussion with sample developer and merchandiser that preproduction and photo sample were taking more time comparing to production sample and size set sample due to followings:

Result and Discussions (Time Study of Sample Approval) a) Printed design development \& redesigning

b) Developing the design of shorts

\section{Experiment No: 01(Figure 12)}

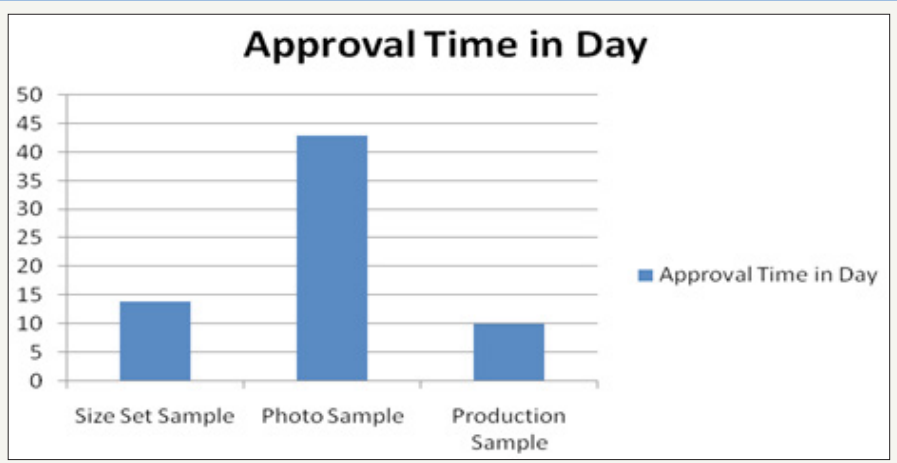

Figure 12: Time of sample approval in day for Size set sample, photo sample and production sample.

Buyer was satisfied with the size set sample and production sample due to fulfil their requirements of this samples don't take much time to be approved, but the approval process of photo sample

\section{Experiment No: 02(Figure 13)}

took more time to be approved due to having more corrections of photo printed design.

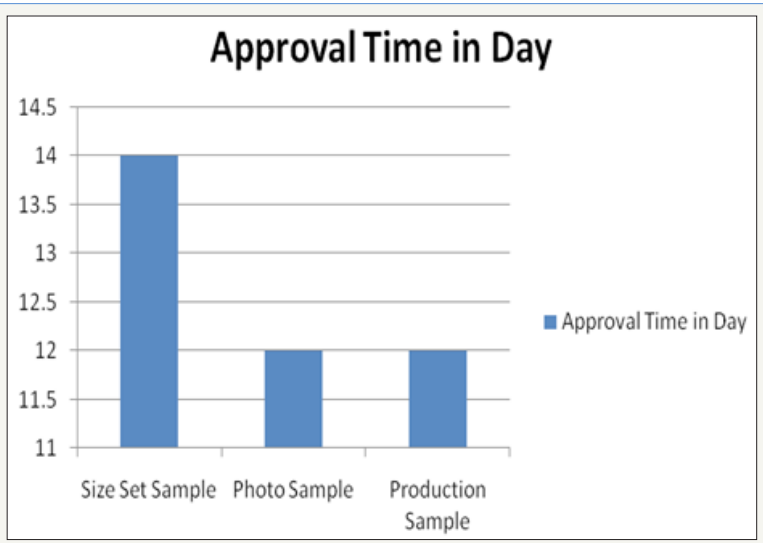

Figure 13: Time of sample approval in day for Size set sample, photo sample and production sample. 
Buyer was satisfied with the photo sample and production sample due to fulfil their requirements of this samples don't take much time to be approved, but size set sample took more time to

\section{Experiment No: 03(Figure 14)}

be approved due to lacking exact measurement as per customer specifications.

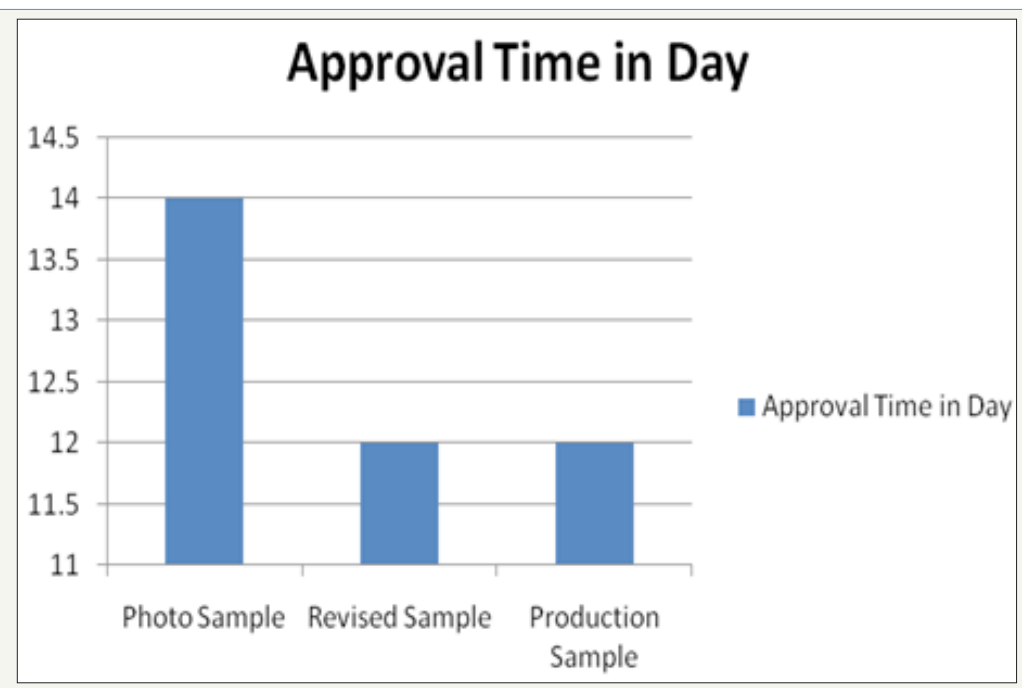

Figure 14: Time of sample approval in day for photo sample, revised sample and production sample.

Buyer was satisfied with the revised and production sample to be approved. But photo sample took more time to be approved due fulfil the buyer requirements of this sample don't take much time to to artwork modification.

\section{Experiment No: 04(Figure 15)}

\section{Approval Time in Day}

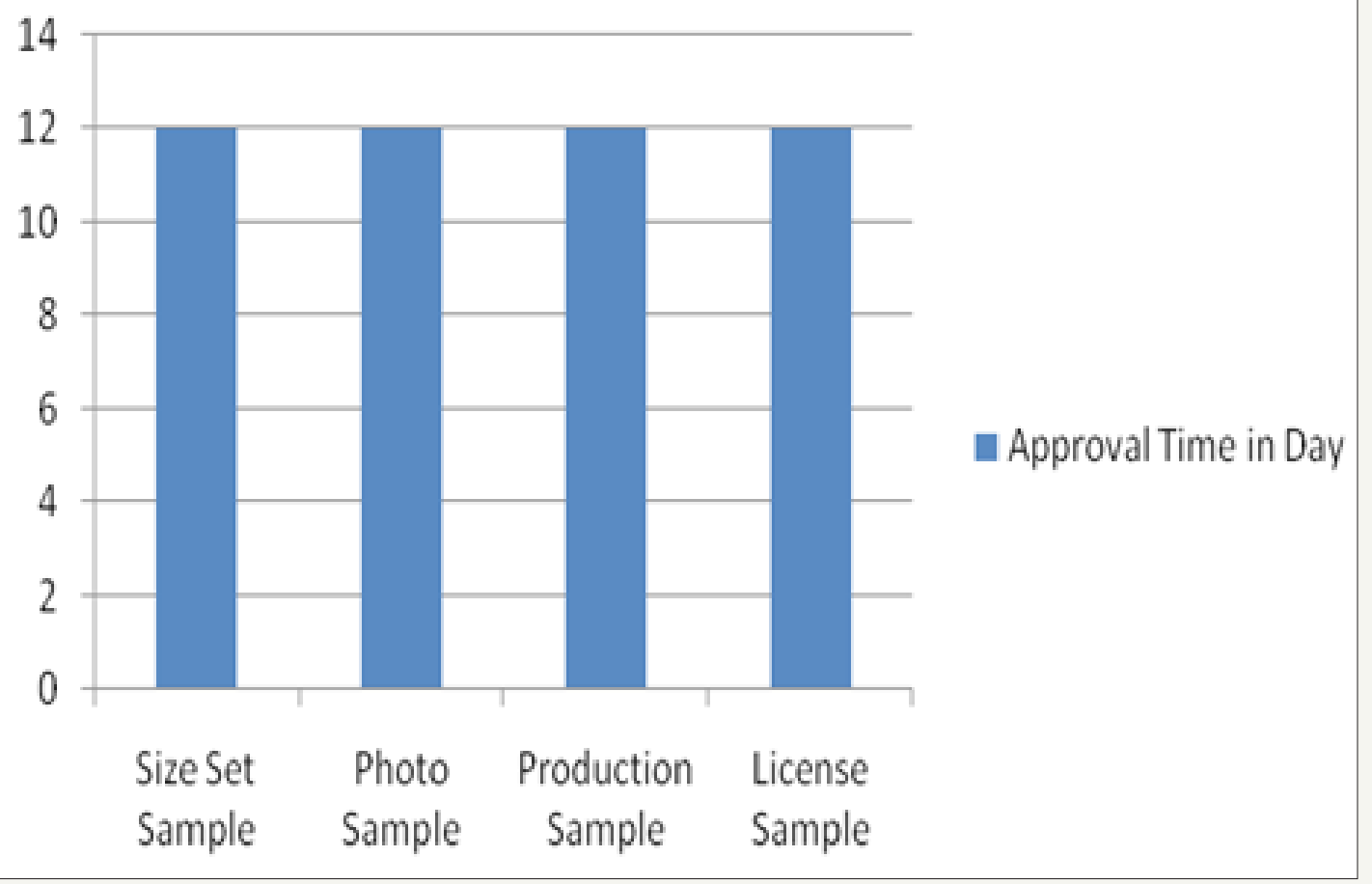

Figure 15: Time of sample approval in day for Size set sample, photo sample, production sample and license sample.

Buyer was not satisfied with all stages of sample developments due to lack of exact understanding from factory concern and took delay approval and also effected to delay production starting and not able to maintain shipment date. 


\section{Experiment No: 05(Figure 16)}

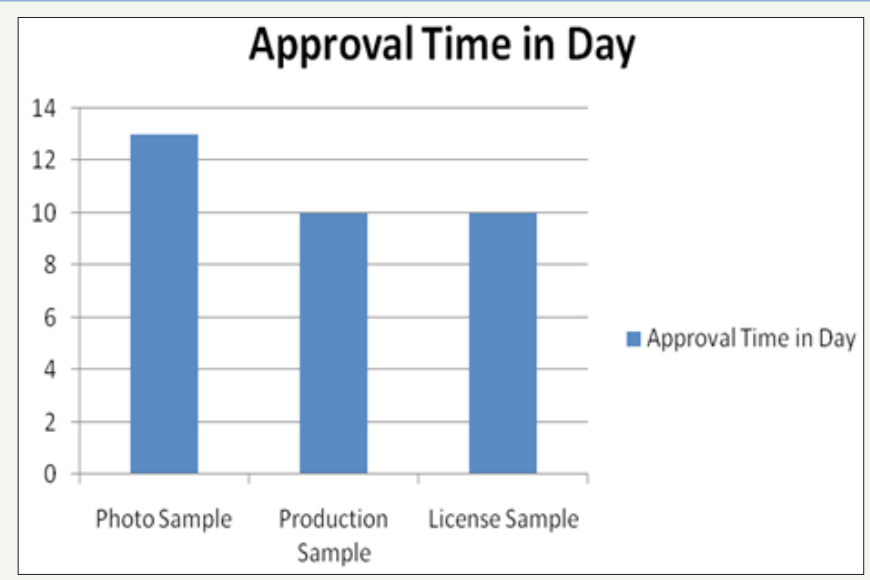

Figure 16: Time of sample approval in day for photo sample, production sample, license sample.

Buyer was almost satisfied with the production and license sample to fulfil the buyer requirements of this sample don't take much time to be approved. But photo sample took more time to be approved due to lacking exact understanding between factory merchandiser and printing designer and sample was submitted to customer around 3 times for getting approval.

\section{Experiment No: 06(Figure 17)}

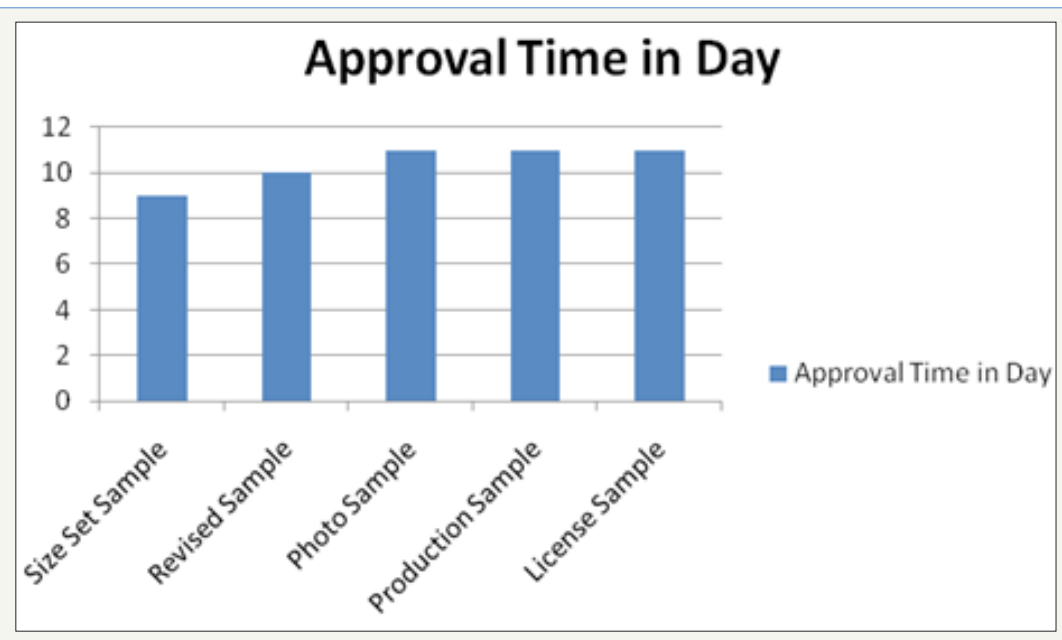

Figure 17: Time of sample approval in day for Size set sample, Revised sample, photo sample, production sample and license sample.

Buyer was not completely satisfied with the all sample like size set, revised, photo, production and license sample due to having so much comments of buyer and second time improvement of sample for getting approval of buying house merchandiser.

\section{Experiment No: 07(Figure 18)}

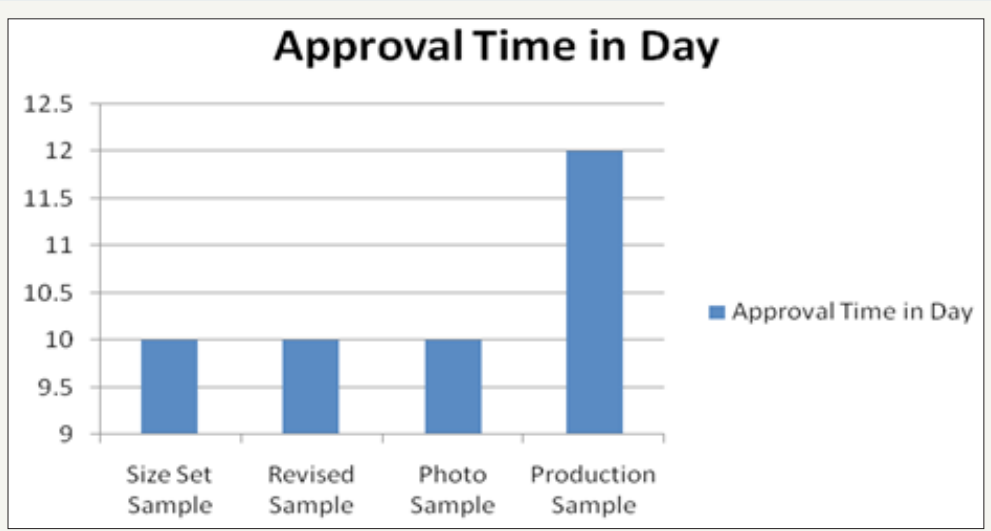

Figure 18: Time of sample approval in day for size set sample, revised sample, photo sample and production sample. 
Production sample was not matching with approved sample for production due to several problems raised in production like

\section{Experiment No: 8(Figure 19)}

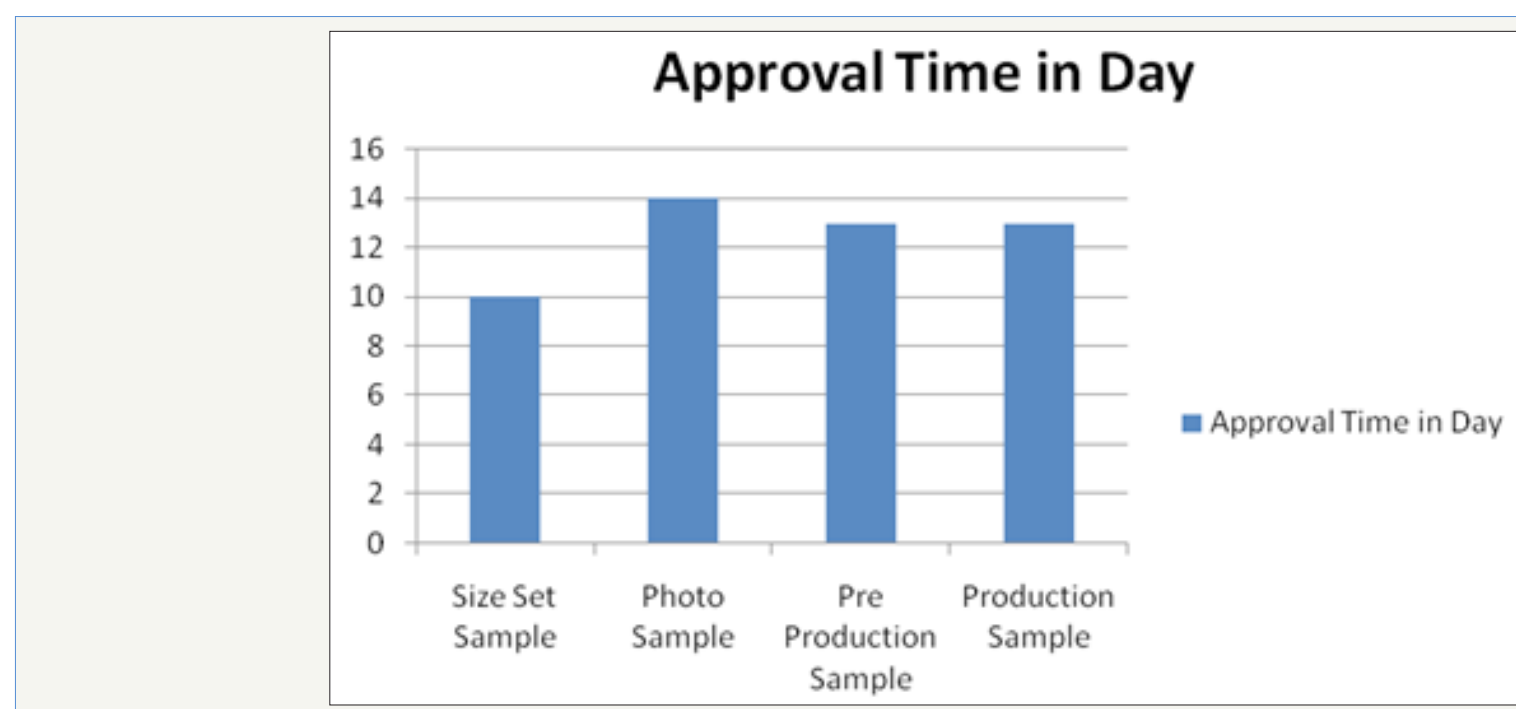

Figure 19: Time of sample approval in day for Size set sample, photo sample, preproduction sample and production sample.

Buyer was commented on developed sample around three times due to failure of buyer specifications in developed sample.

As per time study report of sample production in sample department: Photo sample and revised sample of knit garments like T-Shirt LS Kids), Tops (Ladies), Tops \& Bottom LS (Ladies) and Pant Shorts \& Skirt (Ladies) took more time to fulfill the requirements of buyer where buying house concen was making several comments to make complain of actual fitting of garments.

As per sample approval report: Maximum stages of sample development toom more time due to fufill the buying house merchandiser's requirements and sometimes sample was developed two time and times also and it was several time improved considering the quality of fabric GSM, Fabric color, print design, print color, garments seaming quality as per buyer requirements.

The data shows that the samples are approved in 10 to 43 days. Among all the order of Company A \& B order No 122675 took the maximum time for sample approval and Order No: 123561 took the minimum time for sample approval and among all the order of company, order no 122675 was the minimum order quantity and Order No: 123561 was the maximum order quantity as order was increased by the customer.

\section{Technical Discussion}

Sample develop of a specific buyer of Europe country was observed in a knit garments factory and studied the sample related problem during sample making as well as investigated the time of sample approval where we have found very important result both in technological and marketing which are

1) Fabric problem, color shade matching of fabric, azo \& formaldehyde presence in both fabric dyeing and printing in sample stage, shade matching of accessories \& sewing thread, seam puckering, sewing quality, shrinking of garments, sample finishing \& unskilled technician in sample department were affected the time of sample making and sample approval.

2) Due to technical limitation of photo printing in sample where customers were making demand of actual view \& shade matching of photo print, but in real case it was impossible because of technical limitation by the factory concern which was taking more time of sample making and approval.

3) Color shade matching in printing was not possible like as the matching of fabric color matching which was not accepted by the buying house merchandiser but practically no spectrophotometer machine was using to match the color matching of print design which was taking more time for sample making and sample approval.

4) Sometimes buying house merchandiser was unable to understand the sample making and it was solved by the effective discussion between the experienced holder person \& buying house merchandiser.

Technological Problems were found in garments sample department:

a) Control of thread tension

b) Problem of pucker

c) Irregular movement of fabric during take-up

d) Sewing Dynamics with change in fabric and thread mechanical properties

e) Problem of needle heating and damage

f) Needle penetration force 


\section{Conclusion}

Sampling is the heart of any export order processing. The future of any style purely depends on buyer and factory which are adding value to the samples. So, it is very important to understand the sample development process to control quality and costs in the initial stage or in the sampling development. Merchandiser plays the central role in sampling process as, the only person between the buyer and factory who understands the buyer specification, technical details and time line of sampling. The process of sampling is about the eventual satisfaction of specific needs. It is about products the company can make or out-source profitably for which there is a market demand. Sampling is the best way to place bulk order in any export-oriented factory. The purpose of sampling is not only to get bulk order and also it gives some additional benefits to the exporters. The use of technology, computer-based designing, as well as innovation and creativities may be the important tools in driving apparel sampling. By minimising the trouble shooting in sample production, we can highly minimise the sample development cost it may be written as: Trouble shooting in sample production $=$ cost minimisation $=$ Increasing the profit margin of knit composit factory.

Due to restriction of factory concern it was not possible to collect actual sample of each and every experiment although collected data with discussion among sample developer, merchandiser, technician, related concern of sample development like fabric production, printing concern and accessories suppliers. But we have collected several samples from merchandising department of showing the reality of present work. As per discussion-based references, there is a possibility of error to collect data of this work. So, in future this project may be extended to do survey by staying long time in merchandising and sample department.

Due to administrative difficulties in the factory, it was not possible to collect related email comments between factory merchandiser and buying house merchandiser as well as it was also impossible to collect related testing data of sample development as per buyer specification in order sheet.

\section{Acknowledgement}

Authors are grateful for two Companies A and B, one in in India and one in Bangladesh respectively for cooperating supplying data from their merchandising department for this study.

\section{References}

1. Kastanos E, Christine, Reddy Best L, Kelly (2018) Exploration of communication processes related to the apparel product development process. International Journal of Costume and Fashion 18: 13-31.

2. Liang S (2011) Analysis of the bra design requirements of Fujian female undergraduates. Wool Textile Journal.

3. Pratyush T (2011) Recent trends and development in apparel marketing in India. Journal of Engineering, Science and Management Education 4: 33-37.

4. Archana G, Sunil S. An analysis of responsible factors for merchandiser's performance and role in apparel industry. Metamorphosis- A Journal of Management Research, Indian Institute of Management Lucknow Prabandh Nagar, IIM Road, Lucknow, India.

5. Jae J, Ho J (2015) Consumption of counterfeit luxury fashion products based on the theory of planned behavior. Journal of the Korean Society of Clothing and Textiles 39(3): 433-445.

6. LI Jun, Zhang XF, Feng X (2004) Study on young-adult female consumer in Shanghai and apparel brand merchandising. Journal of Donghua University, p. 4 .

7. (2013) Study on shaping underwear consumption of city women in south Jiangsu and the product strategy china textile leader.

8. Liang S (2011) Analysis of underwear consuming behavior of female undergraduate in Fujian. Journal of Xi'an Polytechnic University, p. 2.

9. Wu, Hong W, Wu X (2005) Research on men's clothing development based on the era of big data network model. Beijing Textile Journal.

10. Zhou L (2010) Study the relationship between the construction and comfort of pants. Journal of Xi'an Polytechnic University.

11. Archana G, Sunil S (2014) Merchandisers' performance and supply chain competitiveness in apparel export. IOSR Journal of Business and Management 16(7): 37-44.

12. Nuruzzaman, Ahasanul H (2009) Lead time management in the garment sector of Bangladesh. European Journal of Scientific Research 33(4): 617-629.

13. Farhan S, Bishwajit BP, Mamun H (2014) A research framework of supply chain management in readymade garments industry of Bangladesh. International Journal of Business and Eco-nomics Research 3(6-1): 3844.

14. Mahmuda A, Haris U (2017) supply chain operation model in terms of raw material in Bangladesh apparel industry. International Journal of Textile Science 6(2): 43-48.

15. Behrooz A, Aynul H (2013) A system dynamics approach to supply chain performance analysis of the ready-made-garment industry in Bangladesh. Ritsumeikan Journal of Asia Pacific Studies 32: 1-11.
Creative Commons Attribution 4.0 International License

For possible submissions Click Here

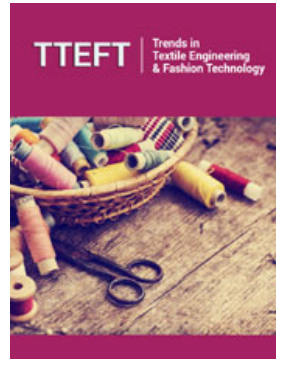

Trends in Textile Engineering \& Fashion Technology

\section{Benefits of Publishing with us}

- High-level peer review and editorial services

- Freely accessible online immediately upon publication

- Authors retain the copyright to their work

- Licensing it under a Creative Commons license

- Visibility through different online platforms 